\title{
The Influence of Radial Slots on Dynamic Stability of Thermally Stressed Circular Saw Blade
}

\section{Utjecaj radijalnih utora na dinamičku stabilnost termički napregnutog lista kružne pile}

\author{
Original scientific paper • Izvorni znanstveni rad \\ Received-prispjelo: 17. 6. 2017. \\ Accepted-prihvaćeno: 1. 12. 2017. \\ UDK: $630 * 822.331 .5$ \\ doi:10.5552/drind.2017.1739
}

\begin{abstract}
The influence of temperature distribution, temperature difference between the rim and centre of the saw blade and the number and size of radial slots on the dynamic stability of the circular saw blade was analysed in this work. The optimum number and size of radial slots for a circular saw blade with a diameter of $300 \mathrm{~mm}$ and a thickness of $2.18 \mathrm{~mm}$ is determined according to the least favourable temperature distribution and temperature difference. The critical rotational speed and lateral stiffness at the rim of the saw blade are considered as criteria for dynamic stability. According to the mentioned criteria, it was found that the optimum number and length of radial slots is 6 and $30 \mathrm{~mm}$, respectively. In some cases, longer radial slots would further increase the critical rotational speed, but would also greatly decrease the lateral stiffness of the saw blade.
\end{abstract}

Keywords: circular saw blade, finite element method, radial slots, critical rotational speed, temperature distribution

SAŽETAK - U radu je analiziran utjecaj raspodjele temperature duž radijusa lista pile, temperaturne razlike između ruba i središta lista pile te utjecaj broja i veličine radijalnih utora na dinamičnu stabilnost kružne pile. Optimalan broj i veličina radijalnih utora za kružnu pilu promjera $300 \mathrm{~mm}$ i debljine 2,18 mm određuje se prema najmanje povoljnoj raspodjeli temperature i temperaturnoj razlici. Kritična brzina vrtnje i lateralna krutost na rubu lista pile smatraju se kriterijima za dinamičku stabilnost. Prema navedenim kriterijima, utvrđeno je da je optimalan broj radijalnih utora šest, a duljina radijalnih utora $30 \mathrm{~mm}$. Dulji radijalni utori u nekim bi slučajevima dodatno povećali kritičnu brzinu vrtnje, ali bi se uvelike smanjila lateralna krutost pile.

Ključne riječi: kružna pila, metoda konačnih elemenata, radijalni utori, kritična brzina vrtnje, raspodjela temperature

\footnotetext{
${ }^{1}$ Authors are assistant professors at University of Ljubljana, Biotechnical Faculty, Department of Wood Science and Technology, Ljubljana, Slovenia.

${ }^{1}$ Autori su docenti Sveučilišta u Ljubljani, Biotehnički fakultet, Odjel za znanost o drvu i drvnu tehnologiju, Ljubljana, Slovenija.
} 


\section{INTRODUCTION}

\section{UVOD}

In the past, a lot of research was focused on the stability of circular saw blade, which is one of the most frequently used woodworking tools. When cutting wood, $12 \%$ of the wood is converted into chips and a further $7 \%$ is lost due to planing required because of rough surfaces caused by low-quality sawing (Schajer and Mote, 1983). To increase the efficiency of circular sawing, manufacturers of circular saw blades tend to make thin and stable circular saw blades.

The stability of circular saw blades has been investigated since the $19^{\text {th }}$ century when Kirchoff, in 1850, published his work about oscillation of elastic discs (Lamb and Southwell, 1921). The first researchers also included Lord Rayleigh (Rayleigh, 1945), who published the work entitled The Theory of Sound in 1877, also describing the vibration of circular discs.

However a more thorough research of the stability of circular saw blades appeared in the 80s and 90s, when the dynamic stability of circular saw blades was analysed by many authors (Mote and Szymani, 1977; Szymani and Mote, 1977; Leu and Mote, 1984; Schajer, 1986; Holøyen, 1987; Hutton, 1991; Nishio and Marui, 1996).

Some authors analysed the influence of rolling on the stability of circular saw blades (Szymani and Mote, 1974; Schajer and Mote, 1983, 1984; Stakhiev, 1999, 2003; Cristovao et al. 2012; Zhang et al. 2014; Li et al., 2015a, 2015b; Li et al. 2016; Li and Zhang, 2017), while others focused on the development of new geometries and modifications of circular saw blades (BeljoLucic and Goglia, 2001; Wasielewski et al., 2012; Droba et al., 2015; Kaczmarek et al., 2016a). In addition, new methods for the verification of dynamic properties of circular saw blades emerged (Orlowski et al., 2007; Vesely et al., 2012; Svoren et al., 2015; Kaczmarek et al., 2016b; Skoblar et al., 2016).

Despite the development of new geometries of circular saw blades, the conventional circular saw blade with radial slots, which compensate the compression of thermal stresses, remains the most common design of circular saw blades. To improve the stability, the impact of temperature distribution and radial slots on the dynamic behaviour of circular saw blades has been analysed by many authors (Mote and Nieh, 1973; Yu and Mote, 1987; Ishihara et al., 2010; Ishihara et al., 2012; Yuan; 2012). Some of them investigated the influence of temperature differences between the rim and centre of the saw blade on the dynamic stability of the saw blade, while others analysed how the saw blades could be stabilised by the guides (Mote et al., 1981; Schajer, 1986; Hutton, 1991).

In addition to the above studies of temperature differences between the rim and centre of the saw blade, an important factor is also the shape of temperature distribution which can be more or less favourable or unfavourable to the dynamic behaviour of the circular saw blade. In wood cutting, the rim of the saw blade has a higher temperature than the rest of the blade, whereby the friction between the saw blade tooth and newly formed chips causes the heating of the rim. In certain cases, the centre of the saw blade is also heated due to the friction in the bearings, especially in long lasting processes, but the temperature is much lower than that at the periphery of the blade.

Despite of numerous studies, there is a lack of research that would include interaction of temperature distribution, temperature difference between the rim and centre of the saw blade, and the number and size of radial slots. This fact is even more evident in circular saw blades available on the market and made by different manufacturers, where saw blades of the same dimension and intended for the same purpose are found to have a different number and size of radial slots. In view of the above mentioned facts, the purpose of this work is to investigate the interactions of these factors, and to determine the optimal number and size of radial slots in the circular saw blade.

\section{MATERIAL AND METHODS} 2. MATERIJAL I METODE

A circular saw blade with a diameter of $300 \mathrm{~mm}$, bore diameter of $30 \mathrm{~mm}$ and thickness of $2.18 \mathrm{~mm}$ was modelled with the finite element method (FEM) using Ansys software. The saw blade had 60 teeth, $9 \mathrm{~mm}$ in height, and it was clamped with a flange of $75 \mathrm{~mm}$ in diameter, which equals $1 / 4$ of the saw blade diameter and thus represents the minimum allowable flange diameter. The density of the steel was $7850 \mathrm{~kg} / \mathrm{m}^{3}$, Young modulus of elasticity $200 \mathrm{GPa}$, Poisson ratio 0.3 , and Coefficient of Thermal Expansion $1.2 \times 10^{-5} \mathrm{~K}^{-1}$. The FEM model had a mesh with around 14400 elements, where default values were used for mesh generation. The saw blade had 4 to 6 radial slots of $15 \mathrm{~mm}$ to 35 $\mathrm{mm}$ in length, with increments of $5 \mathrm{~mm}$.

The internal stresses due to temperature distribution has been incorporated in the saw blade, where $(0$, 40, 80 and 120) ${ }^{\circ} \mathrm{C}$ temperature differences between the rim and centre of the saw blade were used.

The finite element method modal analysis of the circular saw blade, incorporating internal stresses due to temperature distribution, was performed for all combinations of the number and length of the slots and temperature differences.

First the natural frequencies of the stationary saw blade were calculated, and then the calculation was repeated by incorporating additional internal stresses due to rotation, where the saw blade rotated at a rotating speed of 100 rps. In the latter case, the natural frequencies of the rotating saw blade were higher than in the case of the stationary saw blade.

By using the natural frequencies of the rotating and stationary saw blades, the rotational stiffness coefficient $K$ can be calculated for each of the vibration modes, using Eq. 1 (Mote and Szymani, 1977),

$$
K=\frac{v_{\mathrm{m}, \mathrm{n}}^{2}-v_{\mathrm{m}, \mathrm{n}}^{(0)^{2}}}{v_{\mathrm{rot}}{ }^{2}}
$$


a)

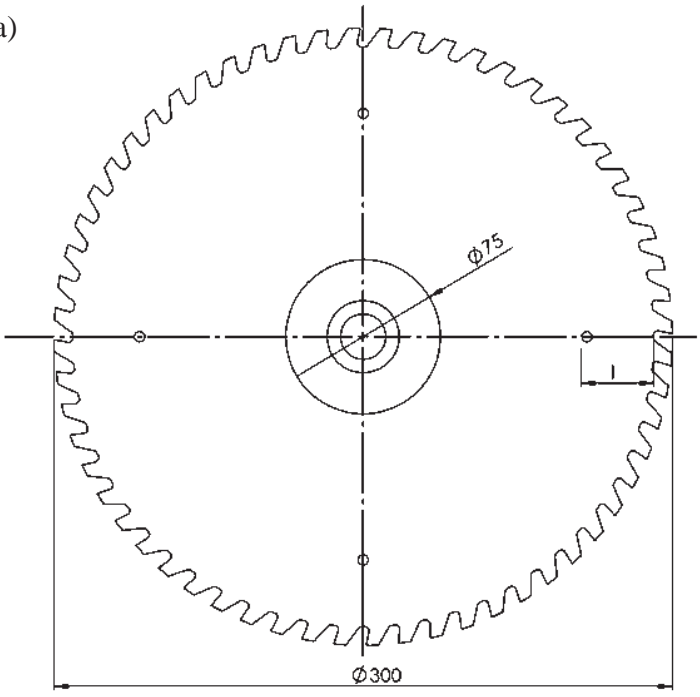

b)

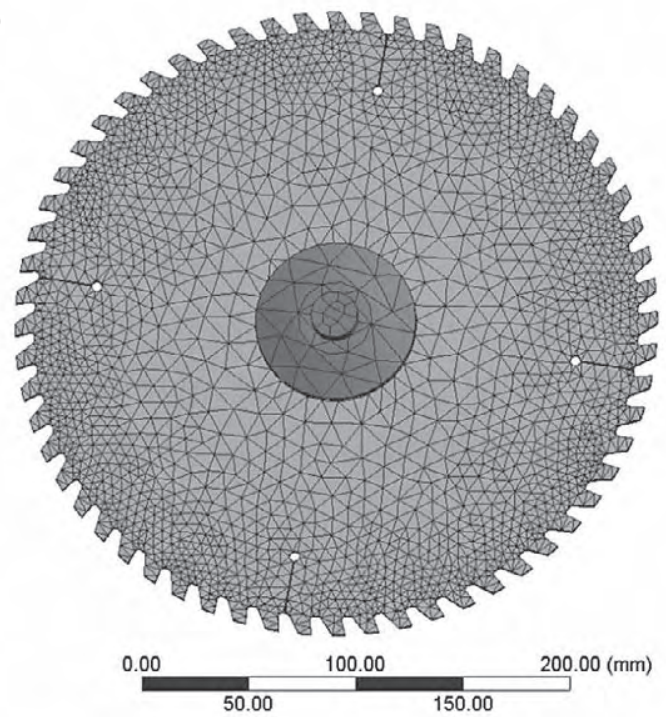

Figure 1 Modelled saw blade. a) Saw geometry, b) Mesh used for computation of FEM

Slika 1. Model lista kružne pile: a) geometrija lista, b) mreža za primjenu metode konačnih elemenata

where $K$ is the rotational stiffness coefficient, $v_{m, n}$ the natural frequency $(\mathrm{Hz})$ of the rotating saw blade for the vibrational mode with $m$ nodal circles and $n$ nodal diameters, $v_{\mathrm{m}, \mathrm{n}}^{(0)}$ is the natural frequency for the stationary saw blade for the vibrational mode with $m$ nodal circles and $n$ nodal diameters and $v_{\text {rot }}$ is the rotational speed.

The critical rotational speed $v_{\text {crit }}$ was calculated for vibrational modes with nodal diameters ranging between 0 and 6 from the calculated rotational stiffness coefficient $K$ and natural frequencies of the stationary saw blades $v_{\mathrm{m}, \mathrm{n}}^{(0)}$, using Eq. 2 (Mote and Szymani, 1977),

$$
v_{\text {crit }}=\frac{v_{\mathrm{m}, \mathrm{n}}^{(0)}}{\sqrt{n^{2}-K}}
$$

Since various vibrational modes have different critical rotational speeds, the lowest calculated value was taken for circular saw blade critical rotational speed.
The buckling temperature was also calculated for each combination of the number and length of the slots. Different authors cite various temperature distributions in the circular saw blade (Mote and Nieh, 1973; Mote et al., 1981; Schajer, 1986), which may be more or less unfavourable in terms of stability of the saw blade, and depend on the working conditions, temperature of the surrounding air, dust suction velocity, convection between the saw blade and air and others. In order to determine the least favourable temperature distribution, 4 additional distributions for the same temperature difference $\left(40^{\circ} \mathrm{C}\right)$ between the rim and centre of the saw blade were used in addition to the temperature distribution of Skoglund (Kollmann and Cote, 1975), as shown in Figure 2. Then the buckling temperatures for the saw blade without and with four $20 \mathrm{~mm}$ slots were calculated for all 5 distributions. The least favourable distribution was taken for further analysis, i.e., distribution, where the buckling temperature was the lowest.

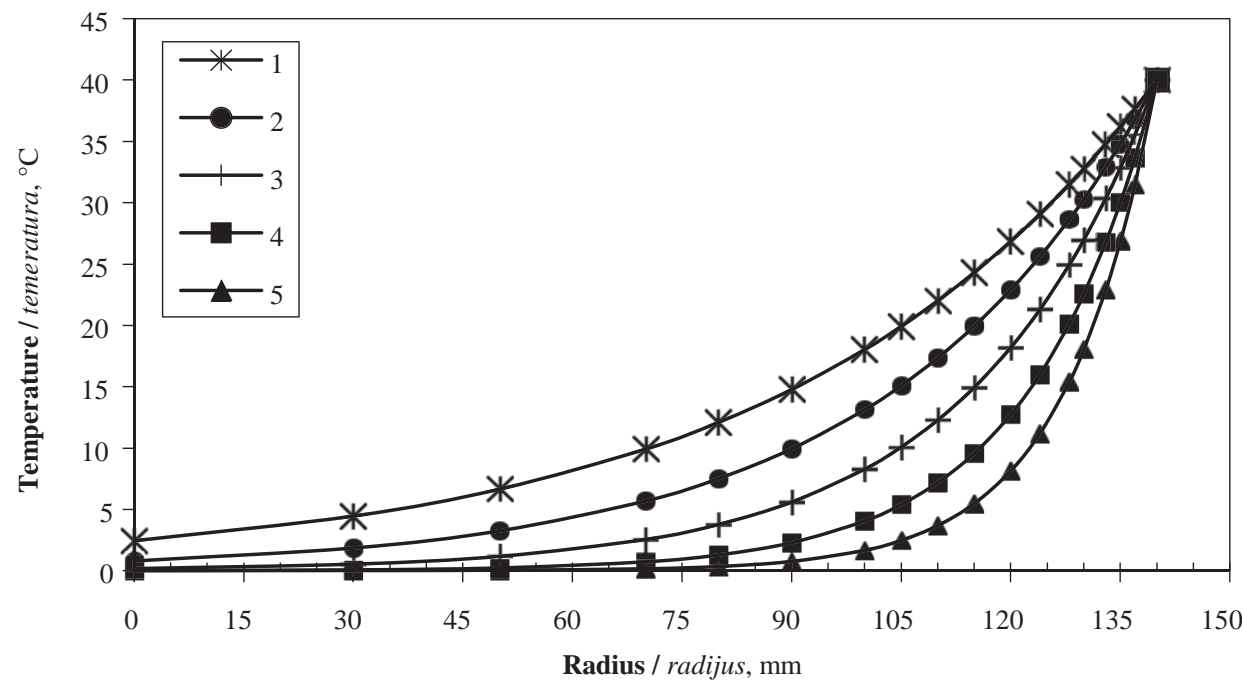

Figure 2 Temperature distributions for $40{ }^{\circ} \mathrm{C}$ temperature difference between the saw blade rim and centre. Distribution Nr. 5 was taken from Skoglund (Kollmann and Cote, 1975)

Slika 2. Raspodjela temperature pri temperaturnoj razlici od $40{ }^{\circ} \mathrm{C}$ između ruba i središta pile; raspodjela broj 5 preuzeta je iz Skoglunda (Kollmann i Cote, 1975.) 
For each combination of the number and length of the slots, the lateral stiffness of the saw blade at the slot and between the slots was also calculated so that the saw blade was loaded with a force of $10 \mathrm{~N}$ at the place of interest, and the lateral stiffness $k$ was calculated from the deformation.

\section{RESULTS \\ 3. REZULTATI}

Table 1 shows the saw blade buckling temperatures for different temperature distributions shown in Figure 2, for a saw blade without slots and one with four $20 \mathrm{~mm}$ slots. It can be seen that temperature distribution No. 2 is the least favourable, since it has the lowest buckling temperature for the saw blade without slots as well as for the saw blade with slots, and it was used in all further analyses as the temperature distribu-
Table 1 Buckling temperatures for different temperature distributions for saw blade without slots and with four 20 mm slots

Tablica 1. Temperature izvijanja lista pile pri različitim raspodjelama temperatura za pilu bez utora i pilu s četiri utora duljine $20 \mathrm{~mm}$

\begin{tabular}{|l|c|c|c|c|c|}
\hline \multirow{2}{*}{} & \multicolumn{5}{|c|}{$\begin{array}{c}\text { Temperature distribution designation } \\
\text { Oznaka raspodjele temperature }\end{array}$} \\
\cline { 2 - 6 } & 1 & 2 & 3 & 4 & 5 \\
\hline $\begin{array}{l}\text { No slots } \\
\text { Bez utora }\end{array}$ & 106 & 99 & 100 & 107 & 119 \\
\hline $4 \times 20 \mathrm{~mm}$ & 141 & 136 & 141 & 158 & 186 \\
\hline
\end{tabular}

tion between the rim and centre of the saw blade as shown in Figure 3.

With increasing length of radial slots, the natural frequencies for vibrational modes from 0 to 6 nodal diameters are decreasing, the least for the vibrational

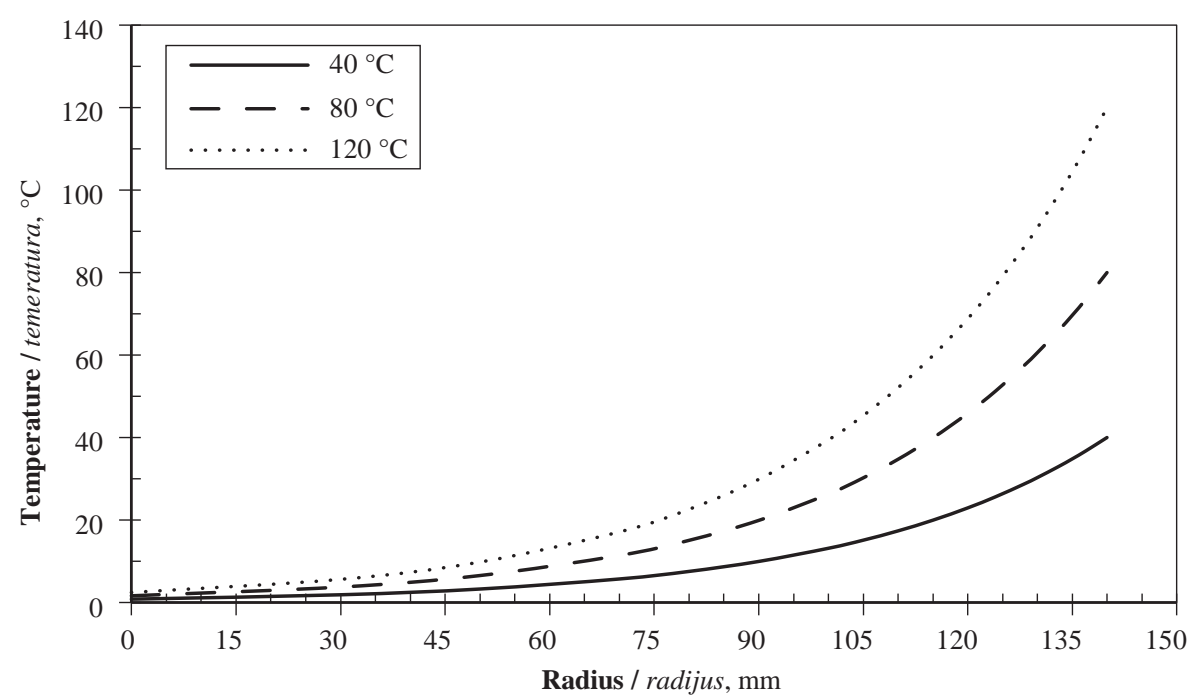

Figure 3 Temperature distributions for $40^{\circ} \mathrm{C}, 80^{\circ} \mathrm{C}$ and $120^{\circ} \mathrm{C}$ temperature difference between the saw blade rim and centre Slika 3. Raspodjela temperature pri temperaturnoj razlici između ruba i središta lista pile od 40, 80 i $120^{\circ} \mathrm{C}$

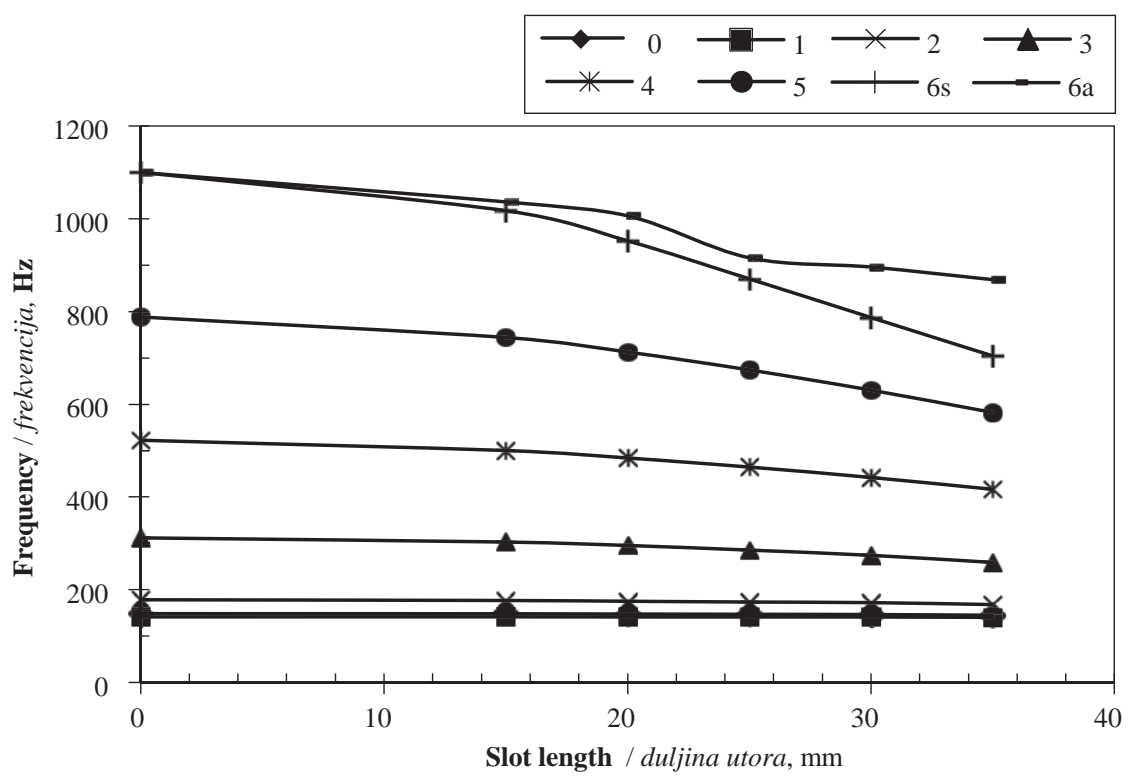

Figure 4 Natural frequencies for different slot lengths for a saw blade with 6 radial slots and zero to six nodal diameters. s-symmetrical mode, a-asymmetrical mode

Slika 4. Vlastite frekvencije lista pile sa šest radijalnih utora pri različitoj duljini utora i 0 - 6 čvornih promjera: s - simetrični mod, a - asimetrični mod 
mode with 0 and 1 nodal diameters, and the most for the vibrational mode with 6 nodal diameters. This relationship for the circular saw with 6 radial slots and temperature difference of $0{ }^{\circ} \mathrm{C}$ is shown in Figure 4 .

However, since the values of natural frequencies give less information than the values of critical rotational speed, the effects of temperature differences and slots on the critical rotational speed will be presented in this paper. Figure 5 shows the calculated critical rotational speeds for all combinations of number and length of the slots, as well as temperature differences between the rim and centre of the saw blade for vibrational mode with 3 nodal diameters, which was found to have the lowest critical rotational speed. It is clear that the critical rotational speed decreases with increasing temperature difference, both for the saw blade with no slots and for the saw blade with slots. It can also be seen that the critical rotational speed at a temperature difference of $0{ }^{\circ} \mathrm{C}$ greatly decreases with increasing length of the slots, namely from 136 rps in the case of the saw blade without slots to 112 rps for the saw blade with four $35 \mathrm{~mm}$ slots, or even down to 102 rps in the case of the saw blade with six $35 \mathrm{~mm}$ slots. However, in case of a temperature difference of $40^{\circ} \mathrm{C}$, the situation is different. In this case, the critical rotational speed for the saw blade without slots amounts to 105 rps, and remains more or less constant when the slot length is increased, while at the length of $35 \mathrm{~mm}$, it is slightly reduced to 102 rps and 96 rps in the case of 4 and 6 slots, respectively.

Increasing the temperature differences between the rim and centre, the slots become even more necessary. At a temperature difference of $80^{\circ} \mathrm{C}$, the critical rotational speed of the saw blade without slots drops to 61 rps, whereas with increasing the slot length, the critical rotational speed increases to reach the maximum value of $91 \mathrm{rps}$ and $92 \mathrm{rps}$ for six $30 \mathrm{~mm}$ slots and $535 \mathrm{~mm}$ slots, respectively.

With further increase of the slot length in the saw blade with 5 slots, the critical rotational speed would

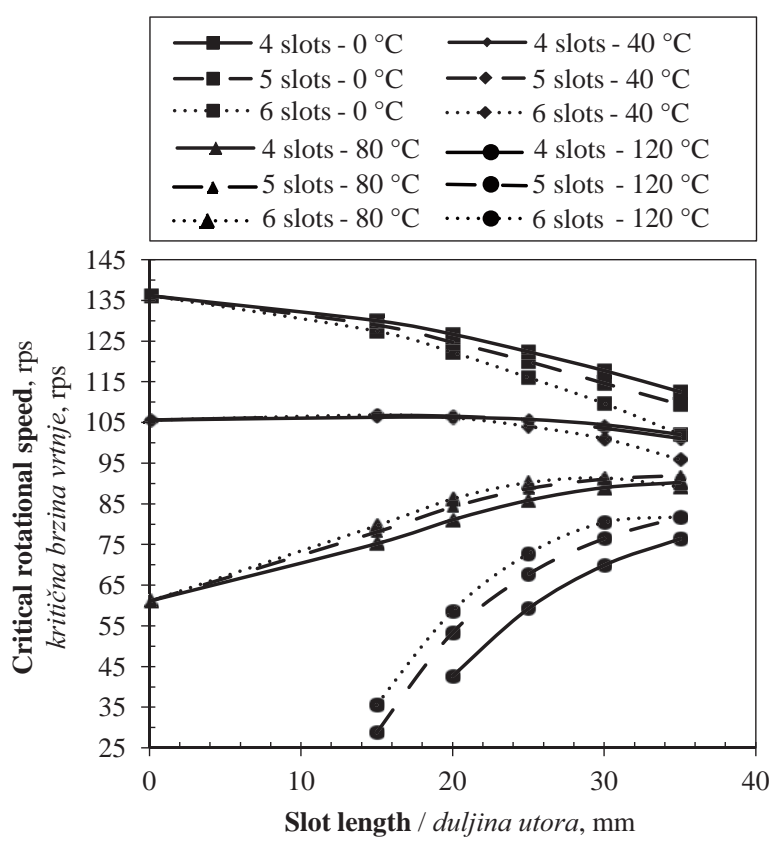

Figure 5 Critical rotational speeds of circular saw blades with different number and length of slots and various temperature differences

Slika 5. Kritične brzine vrtnje kružnih pila s različitim brojem i duljinom utora te pri različitim temperaturnim razlikama

continue to increase, but the lateral stiffness at the rim of the saw blade, as shown in Figure 6, must also be considered in the analysis. The figure indicates that the saw blade without slots has the maximum lateral stiffness amounting to $71 \mathrm{~N} / \mathrm{mm}$, whereas with increasing length and number of slots, the lateral stiffness decreases and it is lower near the slots than at the position between the slots. At six $30 \mathrm{~mm}$ slots, the lateral stiffness in the middle between slots and near the slot is 62 $\mathrm{N} / \mathrm{mm}$ and $54.3 \mathrm{~N} / \mathrm{mm}$, respectively, whereas at five 35 $\mathrm{mm}$ slots, the lateral stiffness for the same location is

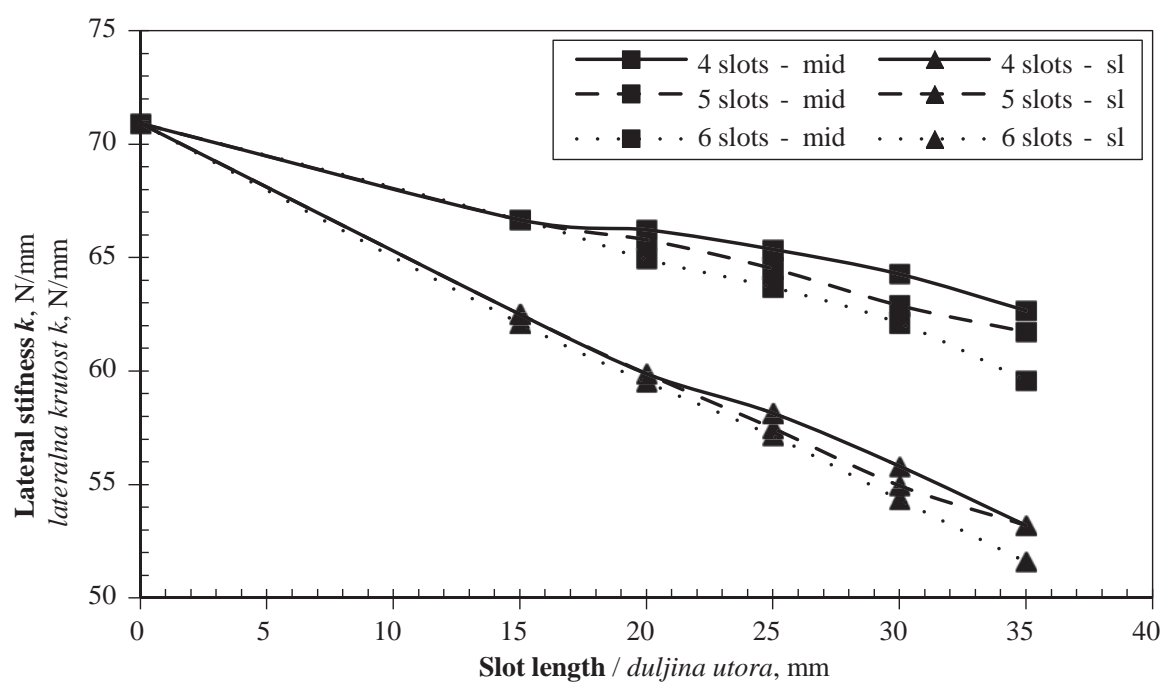

Figure 6 Lateral stiffness of the saw blade at temperature differences of $0{ }^{\circ} \mathrm{C}$ for a different number and length of slots. mid - position between the slots, sl - position near the slot

Slika 6. Lateralna krutost lista pile pri temperaturnim razlikama $0{ }^{\circ} \mathrm{C}$ za različit broj i duljinu utora: mid - položaj između utora, sl - položaj blizu utora 


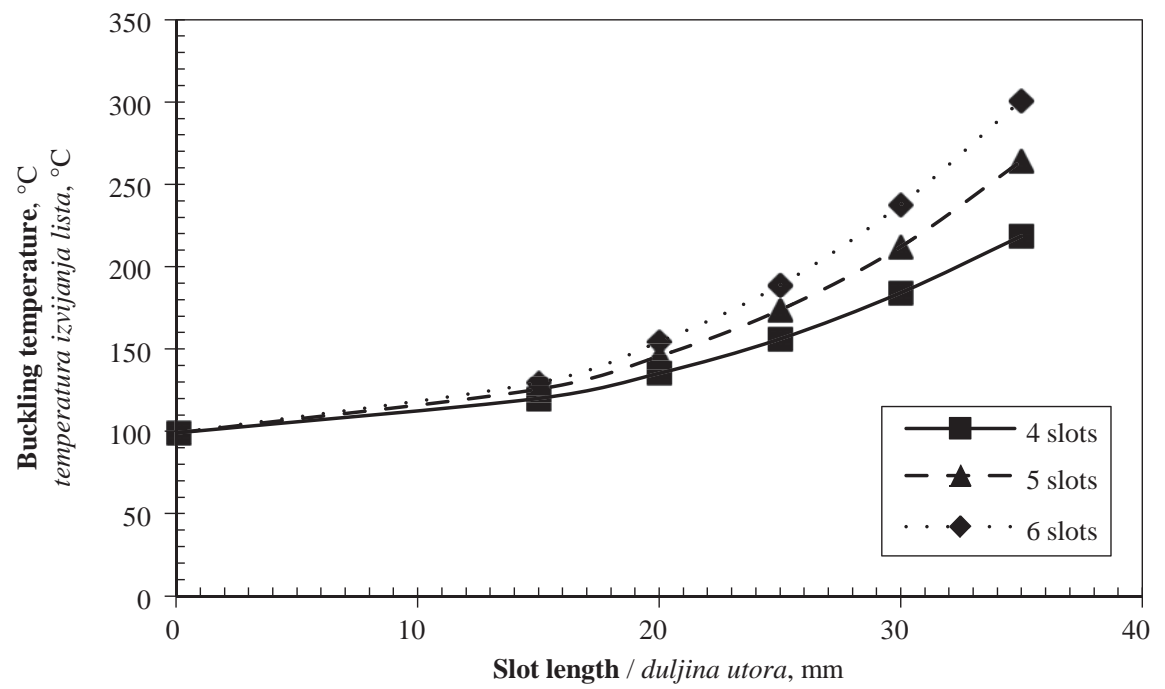

Figure 7 Saw blade buckling temperature for different number and length of slots

Slika 7. Temperatura izvijanja lista pile za različit broj i duljinu utora

61.7 N/mm and $53.2 \mathrm{~N} / \mathrm{mm}$. Taking into account the lateral stiffness, it follows that at a temperature difference of $80{ }^{\circ} \mathrm{C}$, the configuration with six $30 \mathrm{~mm}$ slots is the most favourable combination, since this saw blade has a slightly greater lateral stiffness than that with five $35 \mathrm{~mm}$ slots. With further increase of the slot length in the 5-slot combination, the critical rotational speed would slightly increase, but the lateral stiffness of the saw blade would decrease significantly.

A similar situation occurs at the temperature difference of $120^{\circ} \mathrm{C}$. Here, the saw blade with six 30 and $35 \mathrm{~mm}$ slots has the maximum critical rotational speed of 80.4 and 81.8 rps, respectively, while in the case of five $35 \mathrm{~mm}$ slots, the critical rotational speed is 81.8 rps. As was the case with the temperature difference of 80 ${ }^{\circ} \mathrm{C}$, the combination with six $30 \mathrm{~mm}$ slots is better than the combination with five $35 \mathrm{~mm}$ slots, due to slightly higher lateral stiffness, while the combination with six $35 \mathrm{~mm}$ slots is the worst because of much lower lateral stiffness, which amounts to $59.6 \mathrm{~N} / \mathrm{mm}$ and $51.6 \mathrm{~N} / \mathrm{mm}$ between the slots and near the slot, respectively.

In addition to the critical rotational speed and lateral stiffness, buckling temperatures at which the saw blade dishing occurs were also calculated. Figure 7 shows that, in the case of the saw blade without slots, buckling occurs at a temperature difference of $100{ }^{\circ} \mathrm{C}$, which increases with the number of slots and slot length up to $231{ }^{\circ} \mathrm{C}$ at six $30 \mathrm{~mm}$ slots (Figure 8) or even up to $300{ }^{\circ} \mathrm{C}$ at six $35 \mathrm{~mm}$ slots.

Since the compressive stresses are the most significant for the saw blade stability, Figure 9 shows the tangential stresses in a stationary saw blade and in saw blade rotating at $100 \mathrm{rps}$ for a temperature difference of $80{ }^{\circ} \mathrm{C}$ between the rim and centre of the saw blade. It can be seen that the tangential stresses are lower in the saw blade with six $30 \mathrm{~mm}$ slots than in the saw blade without slots.

The figure also shows lower compressive stresses of the rotating saw blade in the tangential direction due to the centrifugal effect, which is desirable, since the temperature difference between the rim and centre of the saw blade can be increased. However, it should be noted that, when the saw blade stops rotating, the tension due to the centrifugal effect disappears, and the saw blade could buckle. For this reason, it is important to analyse the saw blade in a worst case scenario, which is at rest, when there are no positive stresses caused by the centrifugal effect.

The distribution of internal stresses in the saw blade without slots and with six $30 \mathrm{~mm}$ slots at a temperature difference of $80{ }^{\circ} \mathrm{C}$ for a stationary circular saw blade is shown in Figure 10. It can be seen from the figure that the tangential stresses in the saw blade with slots are mainly compressive and amount to around 10 $\mathrm{MPa}$ in the radius range between 60 and $120 \mathrm{~mm}$, which then increases to about $50 \mathrm{MPa}$ under the teeth and up to $85 \mathrm{MPa}$ under the gullets. In the saw blade without slots, the stress distribution is completely different: in the inner part of the blade up to the diameter of $90 \mathrm{~mm}$, the stresses are tensile and amount to $20 \mathrm{MPa}$, while in the outer part of the blade, the stresses turn to compressive stress of up to $100 \mathrm{MPa}$ below the teeth and up to $200 \mathrm{MPa}$ under the gullets. The figure also shows the distribution of radial stresses, which are very similar for both saw blades and amount to around $50 \mathrm{MPa}$ for saw

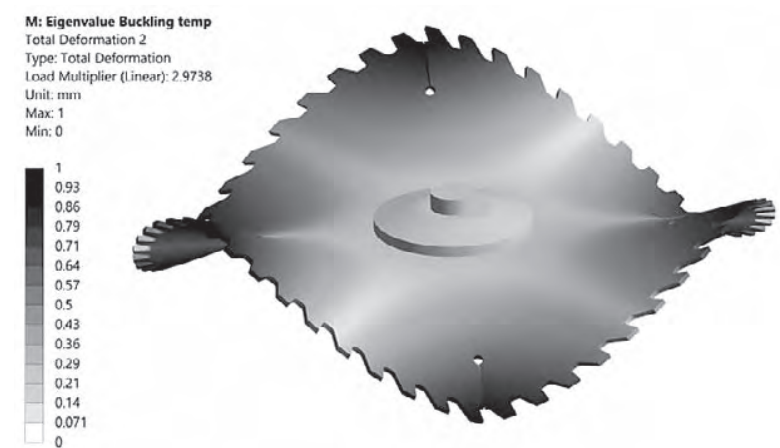

Figure 8 Saw blade buckling mode for $237^{\circ} \mathrm{C}$ temperature difference and combination of six $30 \mathrm{~mm}$ slots

Slika 8. Mod izvijanja lista pile pri temperaturnoj razlici od $237^{\circ} \mathrm{C}$ i kombinaciji od šest utora duljine $30 \mathrm{~mm}$ 

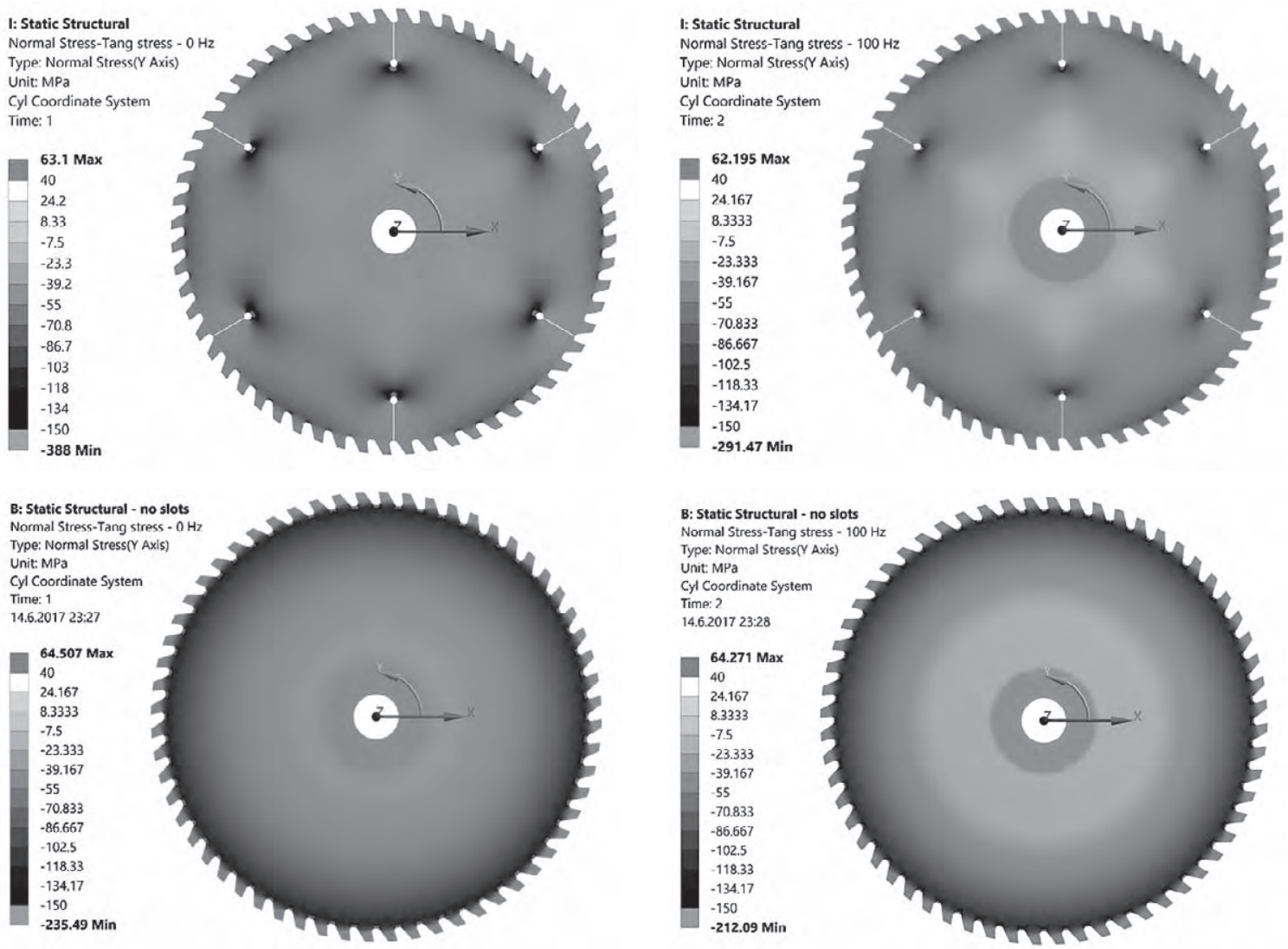

Figure 9 Tangential stresses of stationary and rotating saw blade at a rotational speed of 100 rps without slots and with six 30 mm slots and temperature difference of $80^{\circ} \mathrm{C}$

Slika 9. Tangencijalno naprezanje lista pile u mirovanju i rotirajućeg lista pri brzini vrtnje $100 \mathrm{okr} . / \mathrm{s} \mathrm{bez} \mathrm{utora} \mathrm{i} \mathrm{sa} \mathrm{šest} \mathrm{utora}$ duljine $30 \mathrm{~mm}$ te pri temperaturnoj razlici od $80^{\circ} \mathrm{C}$

blades without slots and 35 MPa for saw blades with slots. The calculated compressive stresses are not significant in comparison to the yield strength of $75 \mathrm{Cr} 1$ steel, which is around $1400 \mathrm{MPa}$ (Heisel, 2015). However, it should be emphasized that the saw blade is slim, and buckling may occur very quickly, particularly in the saw blade without any slots, where the buckling temperature of $100{ }^{\circ} \mathrm{C}$ was calculated.

\section{CONCLUSION 4. ZAKLJUČAK}

The research found that, for certain circular saw blade geometry, there is an optimum number of slots and slot length in case of temperature difference between the saw blade rim and centre. It was also found that different temperature distributions for the same temperature difference have various effects on the sta-

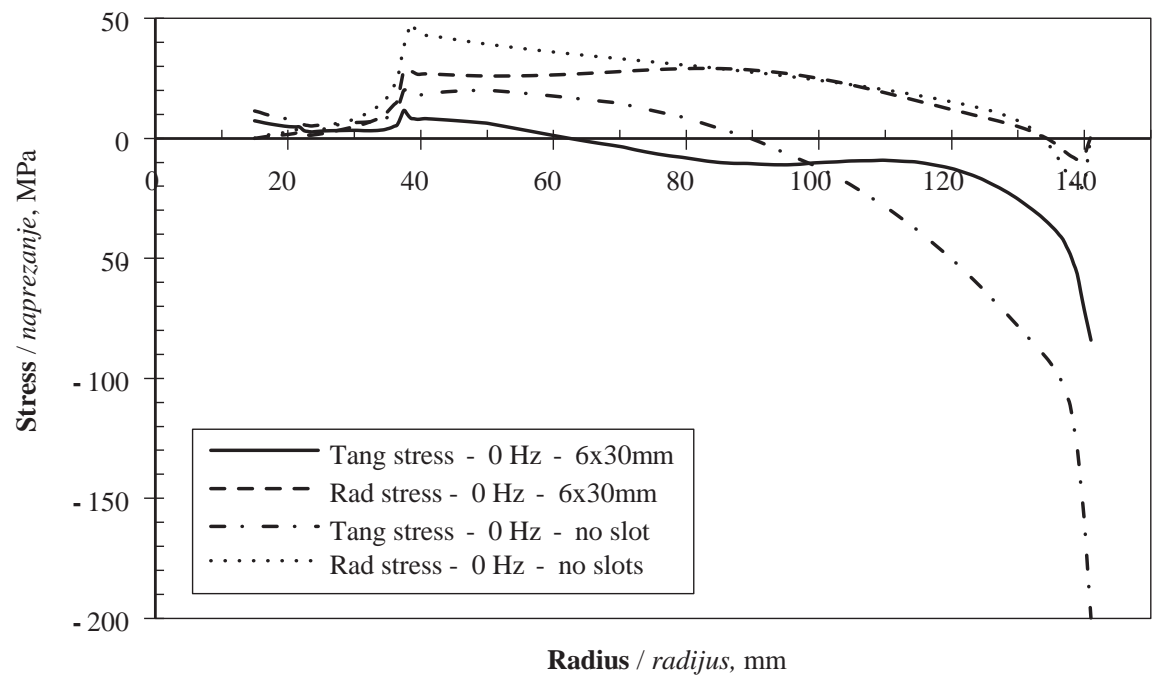

Figure 10 Tangential and radial stress distribution in the stationary circular saw blade without slots and with six $30 \mathrm{~mm}$ slots at a temperature difference of $80^{\circ} \mathrm{C}$

Slika 10. Tangencijalna i radijalna raspodjela naprezanja u listu kružne pile u mirovanju, bez utora i sa šest utora duljine 30 $\mathrm{mm}$ i pri temperaturnoj razlici od $80^{\circ} \mathrm{C}$ 
bility and critical rotational speed of the saw blade. The analysis first determined the least favourable temperature distribution, and then the optimum number of slots and slot length for various temperature differences for the same distribution. It was found that, for the temperature differences greater than $80^{\circ} \mathrm{C}$, the optimum combination for a circular saw blade with a diameter of $300 \mathrm{~mm}$ is six $30 \mathrm{~mm}$ slots. In the case of longer radial slots, the critical rotational speed begins to decrease due to lower lateral stiffness of the circular saw blade.

\section{Acknowledgments - Zahvala}

The authors acknowledge the support of the Slovenian Research Agency within the framework of programs P2-0182.

\section{REFERENCES}

\section{LITERATURA}

1. Beljo Lučić, R.; Goglia, V., 2001: Some possibilities for reducing circular saw idling noise. Journal of Wood Science, 47 (5): 389-393. https://doi.org/10.1007/BF00766791

2. Cristovao, L.; Ekevad, M.; Gronlund, A., 2012: Natural frequencies of roll-tensioned circular sawblades: Effects of roller loads, number of grooves, and groove positions. BioResources, 7 (2): 2209-2219. https://doi.org/10.15376/biores.7.2.2209-2219

3. Droba, A.; Javorek, L.; Svoreň, J.; Paulíny, D., 2015: New design of circular saw blade body and its influence on critical rotational speed. Drewno, 58 (194): 147-157. http://dx.doi.org/10.12841/wood.1644-3985.081.12.

4. Heisel, U.; Stehle, T.; Ghassemi, H., 2015: Experimental investigation into parameters influencing roll tensioning of circular saw blades. Journal of Machine Engineering, 15 (1): 98-111.

5. Holøyen, S., 1987: Vibrations and natural frequencies of angular slot circular saws. Holz als Roh- und Werkstoff, 45 (3): 101-104. https://doi.org/10.1007/BF02605981

6. Hutton, S. G., 1991: The dynamics of circular saw blades. Holz als Roh- und Werkstoff, 49 (3): 105-110. https://doi.org/10.1007/BF02614349

7. Ishihara, M.; Noda, N.; Ootao, Y., 2010: Analysis of dynamic characteristics of rotating circular saw subjected to thermal loading and tensioning. Journal of Thermal Stresses, 33 (5): 501-517. https://doi.org/10.1080/01495731003659208

8. Ishihara, M.; Murakami, H.; Ootao, Y., 2012: Genetic algorithm optimization for tensioning in a rotating circular saw under a thermal load. Journal of thermal stresses, 35 (12): 1057-1075. https://doi.org/10.1080/01495739.2012.720452

9. Kaczmarek, A.; Orłowski, K.; Javorek, L., 2016a: The effect of circular saw blade clamping diameter on its resonant frequencies. Applied Mechanics and Materials, 838: $18-28$ https://doi.org/10.4028/www.scientific.net/AMM.838.18

10. Kaczmarek, A.; Orlowski, K. A.; Javorek, L., 2016b: A brief review and comparison of selected experimental methods for measuring natural frequencies of circular saw blades. Drewno, 59 (197): 231-239. https://doi.org/10.12841/wood.1644-3985.C09.11

11. Kollmann, F. F. P.; Côté, W. A., 1975: Principles of wood science and technology. New York: Springer-Verlag. https://doi.org/10.1007/978-3-642-87931-9

12. Lamb, H.; Southwell, R. V., 1921: The vibrations of a spinning disk. Proceedings of the royal society of Lon- don series a-containing papers of a mathematical and physical character, 99 (699): 272-280. https://doi.org/10.1098/rspa.1921.0041

13. Li, B.; Zhang, Z.; Li, W.; Peng, X., 2015a: Effect of yield strength of a circular saw blade on the multi-spot pressure tensioning process. BioResources, 10 (4): 75017510. https://doi.org/10.15376/biores.10.4.7501-7510

14. Li, B.; Zhang, Z.; Li, W.; Peng, X., 2015b: A numerical simulation on multi-spot pressure tensioning process of circular saw blade. Journal of Wood Science, 61 (6): 578585. https://doi.org/10.1007/s10086-015-1508-5

15. Li, B.; Zhang, Z., 2017: Research on the effect of yield strength of circular saw blade on roll tensioning process. Journal of Wood Science, 63 (2): 140-146. https://doi.org/10.1007/s10086-016-1602-3

16. Li, S.; Wang, C.; Zheng, L.; Wang, Y.; Xu, X.; Ding, F., 2016: Dynamic stability of cemented carbide circular saw blades for woodcutting. Journal of Materials Processing Technology, 238: 108-123.

https://doi.org/10.1016/j.jmatprotec.2016.07.018

17. Leu, M. C.; Mote, C. D., 1984: Origin of idling noise in circular saws and its suppression. Wood Science and Technology, 18 (1): 33-49. https://doi.org/10.1007/BF00632129

18. Mote, C. D.; Nieh, L. T., 1973: On the foundation of circular saw stability theory. Wood and Fiber, 5 (2): 160-169.

19. Mote, C. D.; Szymani, R., 1977: Principal developments in thin circular-saw vibration and control research. I. Vibration of circular saws. Holz als Roh- und Werkstoff, 35 (5): 189-196. https://doi.org/10.1007/BF02610942

20. Mote, C. D.; Schajer, G. S.; Holoyen, S., 1981: CircularSaw Vibration Control By Induction Of Thermal Membrane Stresses. Journal of Engineering For Industry, 103 (1): 81-89. https://doi.org/10.1115/1.3184465

21. Nishio, S.; Marui, E., 1996: Effects of slots on the lateral vibration of a circular saw blade. International Journal of Machine Tools and Manufacture, 36 (7): 771-787. https://doi.org/10.1016/0890-6955(95)00088-7

22. Orlowski, K.; Sandak, J.; Tanaka, C., 2007: The critical rotational speed of circular saw: simple measurement method and its practical implementations. Journal of Wood Science, 53 (5): 388-393.

https://doi.org/10.1007/s10086-006-0873-5

23. Rayleigh, J. W. S., 1945: The theory of sound. New York, Dover, pp. 352-359.

24. Schajer, G. S.; Mote, C. D., 1983: Analysis of roll tensioning and its influence on circular saw stability. Wood Science and Technology, 17 (4): 287-302. https://doi.org/10.1007/BF00349916

25. Schajer, G. S.; Mote, C. D., 1984: Analysis of optimal roll tensioning for circular saw stability. Wood and Fiber Science, 16 (3): 323-338.

26. Schajer, G. S., 1986: Why are guided circular saws more stable than unguided saws? Holz als Roh- und Werkstoff, 44 (12): 465-469. https://doi.org/10.1007/BF02608068

27. Skoblar, A.; Andjelic, N.; Zigulic, R., 2016: Determination of critical rotational speed of circular saws from natural frequencies of annular plate with analogous dimensions. International Journal for Quality Research, 10 (1): 177-192. https://doi.org/10.18421/IJQR10.01-09

28. Stakhiev, Y., 1999: Research on circular saws roll tensioning in Russia: Practical adjustment methods. Holz als Roh- und Werkstoff, 57 (1): 57-62. https://doi.org/10.1007/PL00002622

29. Stakhiev, Y., 2003: Research on circular saw disc problems: Several of results. Holz als Roh- und Werkstoff, 61 (1): 13-22. https://doi.org/10.1007/s00107-002-0353-6

30. Svoren, J.; Javorek, L.; Droba, A.; Pauliny, D., 2015: Comparison of Natural Frequencies Values of Circular 
•... Merhar, Gornik Bučar: The Influence of Radial Slots on Dynamic Stability of Thermally...

Saw Blade Determined by Different Methods. Drvna industrija, 66 (2): 123-128.

https://doi.org/10.5552/drind.2015.1316

31. Szymani, R.; Mote, C. D., 1974: A review of residual stresses and tensioning in circular saws. Wood Science and Technology, 8 (2): 148-161. https://doi.org/10.1007/BF00351369

32. Szymani, R.; Mote, C. D., 1977: Principal developments in thin circular saw vibration and control research. II. Reduction and control of saw vibration. Holz als Roh- und Werkstoff, 35 (6): 219-225. https://doi.org/10.1007/BF02608337

33. Vesely, P.; Kopecky, Z.; Hejmal, Z.; Pokorny, P., 2012: Diagnostics of circular sawblade vibration by displacement sensors. Drvna industrija, 63 (2): 81-86. https://doi.org/10.5552/drind.2012.1130

34. Wasielewski, R.; Orlowski, K. A.; Szyszkowski, S., 2012: Economical wood sawing with circular saw blades of a new design. Drvna industrija, 63 (1): 27-32. https://doi.org/10.5552/drind.2012.1121

35. Yu, R. C.; Mote, C. D., 1987: Vibration of circular saws containing slots. Holz als Roh- und Werkstoff, 45(4): 155-160. https://doi.org/10.1007/BF02627571
36. Yuan, L., 2012: Influence of radial slots on the vibration characteristics of circular saw blade. Applied Mechanics and Materials, 226: 232-236. https://doi.org/10.4028/ www.scientific.net/AMM.226-228.232

37. Zhang, M.; Zhang, Y.; Ke, J.; Li, X.; Cheng, L., 2014: The influence of tangential roller pressure on the stability of circular saw blade. Applied Mechanics and Material, 614: 32-35.

https://doi.org/10.4028/www.scientific.net/AMM.614.32

\section{Coressponding address:}

Assist. Prof. MIRAN MERHAR, Ph.D.

University of Ljubljana

Biotechnical Faculty

Department of Wood Science and Technology

Jamnikarjeva 101

SI-1000 Ljubljana, SLOVENIA

e-mail: miran.merhar@bf.uni-lj.si 